\title{
OPTIMIZATION OF CULTURAL MEDIA FOR JOINT CULTIVATION OF BRADYRHIZOBIUM JAPONICUM AND AZOSPIRILLUM BRASILENSE
}

\section{S. F. Kozar}

Perspective is the creation of microbial preparations based on mixed cultures diazotrophs particular which include Bradyrhizobium japonicum and Azospirillum brasilense bacteria $[1 ; 2]$. This is due to the fact that at joint cultivation of these nitrogen fixers their growth activity is increased, which promotes the obtaining of high titre of microorganisms in biological preparation. In addition, at pre-plant soybean inoculation by nodule bacteria together with azospirillums more nodules appear on the roots of plants, compared to monobacterization, and nitrogen fixation activity increases, which in turn contributes to obtaining additional yield of this legume.

An important and difficult stage of development of microbial preparations is the optimization of the environment for the cultivation of microorganisms, which are their active basis. Especially difficult this task is at simultaneous cultivation of two or more types of bacteria that have different needs for nutrition sources [3].

At this both the availability of specific components of the environment for each type of microorganisms and features of possible competition for certain compounds of nutrients should be ensured.

Based on the above, the goal of the study was the optimization of liquid culture medium content for joint growing of $B$. japonicum and A. Brasilense in periodic culture.

Materials and methods. Objects of the study: B. japonicum M-8 [4], A. brasilense 18-2 [5], A. brasilense 410 [6]. All the microorganisms were obtained from the National Collection of useful soil microorganisms of Institute of Agricultural Microbiology and Agroindustrial Manufacture of NAAS. We express our sincere gratitude to the authors for courtesy strains.

The number of B. japonicum was determined by plate method through depth seeding of suspensions in agar medium based on pea broth [7]. The number of $A$. brasilense was determined by plate method in agar medium of such a composition, $\mathrm{g} / \mathrm{dm}^{3}$ : potato broth -1 , malic acid -3.6 , sucrose $-2.5 ; \mathrm{pH}$ 7.2-7.4 (diluted by $\mathrm{NaOH}$ solution), agar-agar $-11 \mathrm{~g}$.

Petri dishes were kept in an incubator at the temperature of $(28.0 \pm 2.0)^{\circ} \mathrm{C}$. Counting of $B$. japonicum colonies was performed on the tenth day, A. brasilense - on the fourth day.

The cultivation of bacteria was carried out in the vessels of $500 \mathrm{~cm}^{3}$ on the shaker at a frequency of $240 \mathrm{rpm}$. at the temperature of $(28.0 \pm 2.0)^{\circ} \mathrm{C}$. B. japonicum and A. brasilense seeding material were applied in the ratio $1: 1$. The duration of cultivation is 72 hours.

The optimization of the medium was performed using an algorithm for determining the effects of changing factors on the process of joint cultivation of microorganisms Bradyrhizobium and Azospirillum. To do this, based on previously obtained data as for the impact of the sources of nutrients on the growth of B. japonicum and A. Brasilense, the optimization was performed using symmetrical plans all factors of which vary at the same number of levels. The optimization was performed using the method of orthogonal Latin rectangles [8-10]. The criterion of optimization was the number of viable bacterial cells.

Mathematical processing of experimental data was performed by calculating the influence effect on the number of viable cells for all levels of the studied factors. The effect of different levels influence was calculated by the difference of arithmetic average of process output (number of cells) in all versions, where the factor was at this level and the average value of each series of experiments by the formulas:

$b_{0}=\frac{\sum_{j=1}^{N} y_{i}}{N}, b_{i k}=\frac{\sum_{j=1}^{N} y_{i j}^{k}}{N / m}-b_{0}$

where $b_{0}$ - arithmetic average of the number of bacteria in all variants; $\sum_{j=1}^{N} y_{i}$ - total number of bacteria in all variants of the experiment; 
$b_{\text {ik }}$ - effect of each level;

$y_{i}-$ output in the $i$-th variant of

planning;

$\mathrm{N}$ - total number of variants in the

plan;

$\mathrm{m}$ - number of levels of each factor;

$\sum_{j=1}^{N} y_{i j}^{k}$ - the amount of outputs in

those variants of the plan, where i-th

factor was on the k-th level.

Planning matrix was constituted according to the scheme $3 \mathrm{i} 3 \mathrm{k}$ (Table 1), which allowed to study mutual influence of three factors on the growth of B. japonicum and $A$. brasilense on three levels in the conditions of one experiment. Medium after the first phase of optimization was chosen for the basis, which includes: molasses, fodder yeast (dry), glucose, $\left(\mathrm{NH}_{4}\right)_{2} \mathrm{SO}_{4}, \mathrm{KH}_{2} \mathrm{PO}_{4}$, $\mathrm{K}_{2} \mathrm{HPO}_{4} \cdot 3 \mathrm{H}_{2} \mathrm{O}, \mathrm{MgSO}_{4} \cdot 7 \mathrm{H}_{2} \mathrm{O}, \mathrm{CaCO}_{3}$.

Table 1. Scheme of experiment planning with 3 factors and 3 levels of variation

\begin{tabular}{|c|c|c|c|}
\hline \multirow{2}{*}{$\begin{array}{c}\text { Variant } \\
\text { number } \\
j\end{array}$} & \multicolumn{3}{|c|}{ Factors levels $k$} \\
\cline { 2 - 4 } & Factor & Factor & Factor \\
$i_{1}$ & $i_{2}$ & $i_{3}$ \\
\hline 1 & 1 & 1 & 1 \\
\hline 2 & 2 & 1 & 2 \\
\hline 3 & 3 & 1 & 3 \\
\hline 4 & 1 & 2 & 2 \\
\hline 5 & 2 & 2 & 3 \\
\hline 6 & 3 & 2 & 1 \\
\hline 7 & 1 & 3 & 3 \\
\hline 8 & 2 & 3 & 1 \\
\hline 9 & 3 & 3 & 2 \\
\hline
\end{tabular}

Statistical analysis of experiment data was performed using the computer program Statistica 6.0.

\section{Results and discussion.}

The study of growth activity of $B$. japonicum and $J$. brasilense while cultivating in mixed culture was performed in the medium which included the sources of various nutrients, the impact of which we studied at the first phase of its optimization [11]. At the second stage the following levels of components of the medium were established:

- molasses: 10.0; 15.0; $20.0 \mathrm{~g} / \mathrm{dm}^{3}$ $\left(\right.$ step $\left.-5 \mathrm{~g} / \mathrm{dm}^{3}\right)$;
- fodder yeast: $3.0 ; 4.0 ; 5.0 \mathrm{~g} / \mathrm{dm}^{3}$ $\left(\right.$ step $\left.-1 \mathrm{~g} / \mathrm{dm}^{3}\right)$;

- phosphates (1:1) $\left(\mathrm{KH}_{2} \mathrm{PO}_{4}+\right.$ $\mathrm{K}_{2} \mathrm{HPO}_{4} \cdot \bullet 3 \mathrm{H}_{2} \mathrm{O}$ ): $0.3 ; 0.4 ; 0.5 \mathrm{~g} / \mathrm{dm}^{3}$ (step $\left.0.1 \mathrm{~g} / \mathrm{dm}^{3}\right)$.

Analyzing the obtained data of multifactor experiment (Table 2) it should be noted that the number of $B$. japonicum $\mathrm{M}-8$ bacteria at the joint cultivation with $A$. brasilense 18-2 ranged from 1.68 to 6.61 billion cells $/ \mathrm{cm}^{3}$. At this, the number of azospirillums was varying in a narrow range from 0.83 to 2.91 billion cells $/ \mathrm{cm}^{3}$. While obtaining the inoculant for soybeans the focus should primarily be on the rhizobia titre, that's why optimal in this case, in our opinion, should be considered the medium, which is provided in version 6.

The effects of all factors influence on the number of $B$. japonicum $\mathrm{M}-8$, which was cultivated together with $A$. brasilense 18-2 were deducted at their levels. It was found that the maximum effect for molasses in relation to the rhizobia was received at its concentration of $20 \mathrm{~g} / \mathrm{dm}^{3}$ (table 3), in relation to azospirillums - at the concentration of $15 \mathrm{~g} / \mathrm{dm}^{3}$ (table 4). Maximum effects as for the impact of fodder yeast in relation to both studied microorganisms were observed at the use of component concentration of $4.0 \mathrm{~g} / \mathrm{dm}^{3}$. At the study of influence of different content of phosphate salts on the growth of rhizobia the greatest effect was obtained at the use of the minimum concentration of this component, and on the growth of $A$. brasilense 18-2 - at the use of the concentration of $0.5 \mathrm{~g} / \mathrm{dm}^{3}$.

Table 3. Effects of multifactor experiment on optimization of nutrient medium for B. japonicum $M-8$

\begin{tabular}{|c|c|c|}
\hline $\begin{array}{c}\text { Medium } \\
\text { components }\end{array}$ & $\begin{array}{c}\text { Concentration, } \\
\mathrm{g} / \mathrm{dm}^{3}\end{array}$ & Effect \\
\hline \multirow{2}{*}{ Molasses } & 10.0 & -0.82 \\
\cline { 2 - 3 } & 15.0 & 0.13 \\
\cline { 2 - 3 } & 20.0 & 0.69 \\
\hline Fodder yeast & 3.0 & -0.49 \\
\cline { 2 - 3 } & 4.0 & 1.16 \\
\cline { 2 - 3 } & 5.0 & -0.67 \\
\hline $\mathrm{K}_{2} \mathrm{HPO}_{4} \cdot 3 \mathrm{H}_{2} \mathrm{O}$ \\
$+\mathrm{KH}_{2} \mathrm{PO}_{4}(1: 1)$ & 0.3 & 1.22 \\
\cline { 2 - 3 } & 0.4 & 1.00 \\
\cline { 2 - 3 } & 0.5 & -0.22 \\
\hline
\end{tabular}


Table 2. The number of B. japonicum M-8 and A. brasilense 18-2 bacteria in the versions

of multifactor experiment on optimization of nutrient medium, billion cells $/ \mathrm{cm}^{3}$

\begin{tabular}{|c|c|c|c|c|c|}
\hline \multirow{2}{*}{$\begin{array}{c}\text { Experiment } \\
\text { variants }\end{array}$} & Medium components concentration, $\mathrm{g} / \mathrm{dm}^{3}$ & $\begin{array}{c}\text { Number of } B . \\
\text { japonicum } \mathrm{M}-8 \\
\text { bacteria }\end{array}$ & $\begin{array}{c}\text { Number of } A \text {. } \\
\text { brasilense 18- } \\
\text { 2 bacteria }\end{array}$ \\
\hline 1 & 10 & 3 & 0.3 & 2.57 & 1.37 \\
\hline 2 & 15 & 3 & 0.4 & 2.27 & 1.03 \\
\hline 3 & 20 & 3 & 0.5 & 5.91 & 2.67 \\
\hline 4 & 10 & 4 & 0.4 & 5.25 & 2.77 \\
\hline 5 & 15 & 4 & 0.5 & 3.73 & 2.91 \\
\hline 6 & 20 & 4 & 0.3 & 6.72 & 2.63 \\
\hline 7 & 10 & 5 & 0.5 & 1.92 & 1.25 \\
\hline 8 & 15 & 5 & 0.3 & 6.61 & 2.45 \\
\hline 9 & 20 & 5 & 0.4 & 1.68 & 0.83 \\
\hline
\end{tabular}

Table 4. Effects of multifactor experiment on optimization of nutrient medium for A. brasilense 18-2

\begin{tabular}{|c|c|c|}
\hline $\begin{array}{c}\text { Medium } \\
\text { components }\end{array}$ & $\begin{array}{c}\text { Concentration, } \\
\mathrm{g} / \mathrm{dm}^{3}\end{array}$ & Effect \\
\hline \multirow{2}{*}{ Molasses } & 10.0 & -0.19 \\
\cline { 2 - 3 } & 15.0 & 0.14 \\
\cline { 2 - 3 } & 20.0 & 0.05 \\
\hline Fodder yeast & 3.0 & -0.30 \\
\cline { 2 - 3 } & 4.0 & 0.78 \\
\cline { 2 - 3 } & 5.0 & -0.48 \\
\hline $\mathrm{K}_{2} \mathrm{HPO}_{4} \cdot 3 \mathrm{H}_{2} \mathrm{O}$ \\
$+\mathrm{KH}_{2} \mathrm{PO}_{4}(1: 1)$ & 0.3 & 0.16 \\
\cline { 2 - 3 } & 0.4 & -0.45 \\
\cline { 2 - 3 } & 0.5 & 0.28 \\
\hline
\end{tabular}

It should be noted that B. japonicum M-8 bacteria were more sensitive to changes in the concentrations of studied medium components in comparison with $A$. brasilense 18-2 at the cultivation of these microorganisms in a mixed culture.

The number of $B$. japonicum $\mathrm{M}-8$ bacteria at the joint cultivation with $A$. brasilense 410 diazotrophs ranged from 0.76 to 3.20 billion cells $/ \mathrm{cm}^{3}$. The number of azospirillums was varying in the range of 0.70 to 3.34 billion cells $/ \mathrm{cm}^{3}$ at this. Optimum in this case to be considered the medium comprising of molasses at the concentration of $20 \mathrm{~g} / \mathrm{dm}^{3}$, fodder yeast $-5 \mathrm{~g} / \mathrm{dm}^{3}$, phosphates $-0.4 \mathrm{~g} / \mathrm{dm}^{3}$ (table 5).
In the studies of the impact of all factors on the number of $B$. japonicum $M-8$ and $A$. brasilense 410 cultivated together, it was found that the maximum effect of molasses in relation to the studied microorganisms was observed at its concentration in the culture medium at the rate of $20 \mathrm{~g} / \mathrm{dm}^{3}$, which represents its maximum studied value. In the study of the effects of other investigated components it was found (table 6-7) that the greatest impact on the number of grown bacteria was observed at maximum values of concentrations of these components $-5 \mathrm{~g} / \mathrm{dm}^{3}$ of fodder yeast and $0.5 \mathrm{~g} / \mathrm{dm}^{3}$ of the mixture of phosphate salts.

Table 6. Effects of multifactor experiment on optimization of nutrient medium for B. japonicum M-8, billion cells $/ \mathrm{cm}^{3}$

\begin{tabular}{|c|c|c|}
\hline $\begin{array}{c}\text { Medium } \\
\text { components }\end{array}$ & $\begin{array}{c}\text { Concentration, } \\
\mathrm{g} / \mathrm{dm}^{3}\end{array}$ & Effect \\
\hline \multirow{2}{*}{ Molasses } & 10.0 & -0.39 \\
\cline { 2 - 3 } & 15.0 & 0.18 \\
\cline { 2 - 3 } & 20.0 & 0.63 \\
\hline Fodder yeast & 3.0 & -0.16 \\
\cline { 2 - 3 } & 4.0 & -0.11 \\
\cline { 2 - 3 } & 5.0 & 0.69 \\
\hline $\mathrm{K}_{2} \mathrm{HPO}_{4} \cdot 3 \mathrm{H}_{2} \mathrm{O}$ \\
$+\mathrm{KH}_{2} \mathrm{PO}_{4}(1: 1)$ & 0.3 & -0.11 \\
\cline { 2 - 3 } & 0.4 & 0.01 \\
\cline { 2 - 3 } & 0.5 & 0.52 \\
\hline
\end{tabular}


Table 5. The number of B. japonicum M-8 and A. brasilense 410 bacteria in the versions of multifactor experiment on optimization of nutrient medium, billion cells $/ \mathrm{cm}^{3}$

\begin{tabular}{|c|c|c|c|c|c|}
\hline \multirow{2}{*}{$\begin{array}{c}\text { Experiment } \\
\text { variants }\end{array}$} & \multicolumn{3}{|c|}{ Medium components concentration, $\mathrm{g} / \mathrm{dm}^{3}$} & \multirow{2}{*}{$\begin{array}{c}\text { Number of } B \text {. } \\
\text { japonicum } \mathrm{M}-8 \\
\text { bacteria }\end{array}$} & \multirow{2}{*}{$\begin{array}{c}\text { Number of } A \text {. } \\
\text { brasilense } 410 \\
\text { bacteria }\end{array}$} \\
\hline & Molasses & Fodder yeast & $\begin{array}{l}\mathrm{K}_{2} \mathrm{HPO}_{4} \cdot 3 \mathrm{H}_{2} \mathrm{O} \\
+\mathrm{KH}_{2} \mathrm{PO}_{4}(1: 1)\end{array}$ & & \\
\hline 1 & 10 & 3 & 0.3 & 1.20 & 1.90 \\
\hline 2 & 15 & 3 & 0.4 & 1.83 & 2.20 \\
\hline 3 & 20 & 3 & 0.5 & 2.24 & 2.56 \\
\hline 4 & 10 & 4 & 0.4 & 0.76 & 0.70 \\
\hline 5 & 15 & 4 & 0.5 & 2.46 & 3.00 \\
\hline 6 & 20 & 4 & 0.3 & 2.21 & 1.33 \\
\hline 7 & 10 & 5 & 0.5 & 2.62 & 3.08 \\
\hline 8 & 15 & 5 & 0.3 & 2.01 & 1.23 \\
\hline 9 & 20 & 5 & 0.4 & 3.20 & 3.34 \\
\hline
\end{tabular}

Table 7. Effects of multifactor experiment on optimization of nutrient medium for $A$. brasilense 410, billion cells $/ \mathrm{cm}^{3}$

\begin{tabular}{|c|c|c|}
\hline $\begin{array}{c}\text { Medium } \\
\text { components }\end{array}$ & $\begin{array}{c}\text { Concentration, } \\
\mathrm{g} / \mathrm{dm}^{3}\end{array}$ & Effect \\
\hline \multirow{3}{*}{ Molasses } & 10.0 & -0.11 \\
\cline { 2 - 3 } & 15.0 & 0.14 \\
\cline { 2 - 3 } & 20.0 & 0.41 \\
\hline Fodder yeast & 3.0 & 0.22 \\
\cline { 2 - 3 } & 4.0 & -0.32 \\
\cline { 2 - 3 } & 5.0 & 0.55 \\
\hline $\mathrm{K}_{2} \mathrm{HPO}_{4} \cdot 3 \mathrm{H}_{2} \mathrm{O}$ \\
$+\mathrm{KH}_{2} \mathrm{PO}_{4}(1: 1)$ & 0.3 & -0.51 \\
\cline { 2 - 3 } & 0.4 & 0.08 \\
\cline { 2 - 3 } & 0.5 & 0.88 \\
\hline
\end{tabular}

Based on these data, we can note that to achieve maximum impact on the growth of B. japonicum $\mathrm{M}-8$ and J. brasilense 410 bacteria high concentrations of fodder yeast and phosphates are required.

Thus, by the results of multifactor experiment an optimized medium for joint growing of rhizobia and different strains of azospirillums was offered. It is shown that the effect of molasses, fodder yeast and phosphates influence on growth activity of $B$. japonicum depends not only on the amount of chemicals in the medium, but also on $A$. Brasilense strain which is jointly cultivated with. 